\title{
ADAM ȘI HRISTOS, SIMILITUDINI SOTERIOLOGICE ( I ) RECAPITULARE ȘI RESTAURARE
}

Cosmin Ionel MAFTEI ${ }^{*}$

\begin{abstract}
Adam and Christ, soteriological similarities (I). Summarization and Restoration ${ }^{1}$. In his Epistle to Romans and in the First Epistle to Corinthians Saint Paul makes an antinomian parallel between Adam and Christ, between the first and the second Adam. The same idea is presented by Saint Irenaeus in order to develop the doctrine about everyone's summarization and restoration in Christ. So being said, there are many similarities between Adam and Christ, between the paths Adam took and the restoration accomplished by the New Adam. This similarities will be identified with the help of The Holy Scriptures and the help of The Fathers of the Church in order to discover the details of the work Christ did for redeeming, restoring and summarizing the first Adam and fulfilling, at the same time, the purpose of Creation, the unification with God.
\end{abstract}

Keywords: Incarnation, The Second Adam, grace, Eva, Church.

\section{Introducere}

În Epistola către Romani, Sfântul Apostol Pavel face o paralelă antinomică între Adam, primul om, și Hristos, Omul-Dumnezeu, zicând: ,precum prin greşeala unuia a venit osânda pentru toţi oamenii, aşa şi prin îndreptarea adusă de Unul a venit, pentru toţi oamenii, îndreptarea care dă viaţă; Căci precum prin neascultarea unui om s-au făcut păcătoşi cei mulţi, tot aşa prin ascultarea unuia se vor face drepţi cei mulţi” (Romani 5, 18-19); comparație pe care o continuă în I Corinteni unde spune: „Că

* Priest, PhD Student, Faculty of Orthodox Teology „Ilarion V. Felea” at „Aurel Vlaciu” University, Arad, Romania.

${ }^{1}$ Realizat sub îndrumarea ÎPS Prof. Univ. Dr. Irineu Pop, Universitatea „1 Decembrie 1918" din Alba Iulia, care şi-a exprimat acordul pentru publicare. 
de vreme ce printr-un om a venit moartea, tot printr-un om şi învierea morţilor. Căci, precum în Adam toţi mor, aşa şi în Hristos toţi vor învia,, (I Corinteni 15, 21-22).

Continuând paralela Sfântul Apostol Pavel identifică în Adam primul om și în Hristos al doilea om, afirmând: „Precum şi este scris: Făcutu-s-a omul cel dintâi, Adam, cu suflet viu; iar Adam cel de pe urmă cu duh dătător de viaţă; Omul cel dintâi este din pământ, pământesc; omul cel de-al doilea este din cer" (I Corinteni 15; 45, 47). Cu alte cuvinte Hristos este Adam cel Nou sau ,al doilea Adam”, primul Adam fiind luat din pământ și înzestrat cu „suflet viu”, după chipul și asemănarea lui Dumnezeu, despicând astfel în două istoria lumii materiale ca noutate și punct de referinţă pentru toată creația, iar al doilea Adam-Iisus Hristos este venit din cer având „,duh dătător de viață", împărțind astfel istoria creației și a omenirii în două ${ }^{2}$ prin Intruparea Sa, săvârşind ,cea mai mare noutate din toate noutăţile, singurul lucru nou sub soare, prin care se arată puterea infinită a lui Dumnezeu"3.

Prin Întruparea Sa Hristos reia chemarea lui Adam reorientându1 spre Dumnezeu, „de aceea toate cele ce se întâmplă în naşterea, viaţa şi moartea Sa au similitudini cu cele întâmplate în viața primului Adam. Ca Nou Adam, Hristos „,desface” ceea ce a făcut Adam și împlinește El ceea ce acesta n-a împlinit" ". În acest sens, textele pauline din Romani şi I Corinteni amintite mai sus care prezintă antinomia dintre primul Adam şi al doilea Adam, precum și textele din Efeseni ${ }^{5}$ și Coloseni ${ }^{6}$, ,au constituit matricea Sfântului Irineu referitoare la recapitulare"7. Astfel, Sfântul Irineu afirmă: „Atunci când Fiul lui Dumnezeu a luat Trup și S-

${ }^{2}$ Boris RădUlEAnU, Înnoirea lumii în Iisus Hristos, București, Edit. Bonifaciu, 1997, p. 9.

3 Sfântul IoAn Damaschin, Dogmatica, trad. Dumitru Fecioru, București, Edit. Institutului Biblic și de Misiune al Bisericii Ortodoxe Române, 2005, p. 115.

${ }^{4}$ Calinic Berger, Provocări ale gândirii și vieții ortodoxe astăzi - reflecții despre temeiurile creștine, trad. Maria-Cornelia și Ioan I. Ică jr, Sibiu, Edit. Deisis, 2012, p. 10.

5 ,Făcându-ne cunoscută taina voii Sale, după buna Lui socotinţă, astfel cum hotărâse în Sine mai înainte, Spre iconomia plinirii vremilor, ca toate să fie iarăşi unite în Hristos, cele din ceruri şi cele de pe pământ - toate întru El” (Efeseni 1, 9-10).

${ }^{6}$ „Căci în El a binevoit (Dumnezeu) să sălăşluiască toată plinirea. Şi printr-Însul toate cu Sine să le împace, fie cele de pe pământ, fie cele din ceruri, făcând pace prin El, prin sângele crucii Sale" (Coloseni 1, 19-20).

7 Teofil TIA, Reîncreștinarea Europei? Teologia religiei în pastorala și misiologia occidentală contemporană, Alba Iulia, Edit. Reîntregirea, 2003, p. 295. 
a făcut Om, El a recapitulat în Sine întreaga istorie a omenirii, aducându-ne răsplata mântuirii, așa încât am dobândit în Hristos Iisus tot ceea ce pierdusem prin Adam, adică chipul și asemănarea cu Dumnezeu" 8 .

Potrivit Sfântului Irineu recapitularea tuturor în Hristos, restaurarea și desăvârșirea întregii creații, are o dimensiune cosmică şi eshatologică, ea începe cu Întruparea și culminează cu Pogorârea Duhului Sfânt, fiind în strânsă legătură cu recapitularea lui Adam, drept pentru care Hristos este Noul Adam care se pune în situaţia primului Adam, fiind ,fiul lui Adam” și „Fiul lui Dumnezeu” (cf. Luca 3, 38), după cum arată genealogia lucanică pe baza căreia Sfântul Irineu arată că Hristos unește începutul cu sfârșitul recapitulând totul întru Sine?.

Recapitularea tuturor în Hristos are ca scop restaurarea omului în special şi a Adamului cosmic în general, restaurare care începe cu Întruparea Fiului lui Dumnezeu și se desăvârșește prin lucrarea mântuirii realizată de către Hristos prin întreita Sa demnitate: profetică, arhierească și împărătească, după cum arată și preotul profesor Dumitru Stăniloae ${ }^{10}$. Mai mult decât atât, centralitatea restaurării omului o reprezintă răscumpărarea, izbăvirea, salvarea sau eliberarea ontologică din moarte ${ }^{11}$, conform mărturiei pauline: ,Întru El avem răscumpărarea prin sângele Lui şi iertarea păcatelor, după bogăţia harului Lui” (Efeseni 1, 7) sau cum spune în altă parte: ,Ştiind că nu cu lucruri stricăcioase, cu argint sau cu aur, aţi fost răscumpăraţi din viaţa voastră deşartă, lăsată de la părinţi, ci cu scumpul sânge al lui Hristos, ca al unui miel nevinovat şi neprihănit" (I Petru 1, 18-19).

Iisus Hristos a venit în lume ca să-și dea viaţa, sufletul, ca „răscumpărare” (gr. lutron) pentru omul căzut, de aceea „S-a dat pe Sine preț de răscumpărare pentru toţi”" (I Timotei 2, 3-6). Iată, dar, că Hristos

${ }^{8}$ Sfântul IRINEU DE LugdunUM, ,IImpotriva ereziilor, III, 18”, apud Adrian Lucian Dinu, Maica Domnului în teologia Sfinților Părinți, Iași, Edit. Doxologia, 2009, p. 41.

9 Ioan GoJe, Sfântul Irineu: apărător al învățăturii creștine, Cluj-Napoca, Edit. Renașterea, 2002, p. 236-245.

${ }^{10}$ Dumitru StĂNILOAE, Iisus Hristos sau Restaurarea Omului, ediția a II-a, Craiova, Edit. Omniscop, 1993.

${ }^{11}$ Constantin GaleRIU, Jertfă și Răscumpărare, București, Edit. Harisma, 1991, p. 152. 
S-a dat pe Sine „preț de răscumpărare” (gr. antilutron) pentru toți, încât moartea Sa este ,antidot” pentru moartea noastră și „remediu” pentru păcatul nostru. $\mathrm{Cu}$ alte cuvinte, Hristos ne răscumpără plătind prețul libertății noastre, preț pe care noi nu 1-am fi putut plăti niciodată ${ }^{12}$. Ca Adam cel nou, al doilea Adam, lucrarea lui Hristos ,,se urcă prin adâncul istoriei până la Adam ca să vindece efectele păcatului în toți. Răscumpărarea este, în acest sens, reluarea a ceea ce a compromis Adam"13.

Din acest punct de vedere dogma răscumpărării este de o importanță capitală pentru gândirea teologică a Bisericii, căci ea ocupă un loc central în iconomia divină față de lumea căzută și se concretizează prin pătimirea, moartea și Învierea lui Hristos ${ }^{14}$. Sfântul Nicolae Cabasila sintetizează acest lucru prin cuvintele: „trei piedici stau în calea omului spre Dumnezeu: firea, păcatul și moartea. Din cele trei piedici Domnul îi dă omului putere să se elibereze, chiar să se unească cu Sine, după ce le-a înlăturat pe toate una după alta: pe cea a firii prin întrupare, pe a păcatului prin răstignire, iar zidul cel din urmă, al mortii celei tiranice -din care a ridicat toată firea-, prin înviere" 15 .

În cele ce urmează vom identifica cu ajutorul Sfintei Scripturi și a Sfinților Părinți similitudinile soteriologice, asemănările și deosebirile dintre cei doi Adami accentuând de fiecare dată recapitularea și restaurarea pe care o face Hristos, noul Adam, în vederea îndumnezeirii celui dintâi. Sau după cum spune părintele profesor Ion Buga: „în paralelismul Întemeierii, Adam-Hristos, vom observa corespondențe uluitoare și diferențe specifice, hotărâtoare, într-o synontologie teandrică atotcuprinzătoare" 16 .

${ }^{12}$ William BARClay, Analiză semantică a unor termeni din Noul Testament, trad. Doris Laurențiu, Editor John F. Tipei, USA, Illinois, Wheaton, Edit. Societatea Misionară Română, 1992, p. 202.

${ }^{13}$ Boris RĂDULEANU, Înnoirea lumii în Iisus Hristos, p. 11-12.

${ }^{14}$ Vladimir Lossky, După chipul şi asemănarea lui Dumnezeu, trad. Anca Manolache, Bucureşti, Edit. Humanitas, 2006, p. 98.

${ }^{15}$ Sfântul niColae Cabasila, Despre viața în Hristos, trad. Teodor Bodogae, București, Edit. Institutului Biblic şi de Misiune al Bisericii Ortodoxe Române, 2001, p. 98.

${ }^{16}$ Ion BugA, Carantania și Ghetsimani: cele patru ispitiri ale Mântuitorului și umanității, București, Edit. Sfântul Gheorghe-Vechi, 2012, p. 8. 


\section{Adam „după Chipul lui Dumnezeu” versus Hristos „Chipul lui Dumnezeu"}

Potrivit Genezei, Dumnezeu cel Unul în Ființă și Întreit în Persoane 1-a creat pe om „după chipul Său” (Facere 1, 26-27) luând țărână din pământul proaspăt creat și suflând în fața lui „suflare de viaţă şi s-a făcut omul ființă vie" (Facere 2,7). Sfântul Vasile cel Mare spune în acest sens că „A suflat în fața lui, adică a pus în om o parte din harul Lui, ca ceea ce este asemenea să cunoască pe Cel asemenea"17. În schimb, Hristos este „chipul lui Dumnezeu” (II Corinteni 4, 4; Coloseni 1, 15), „Fiul lui Dumnezeu" ${ }^{\prime 18}$ care S-a întrupat din Fecioară „pentru a arăta și El o întrupare asemănătoare cu cea a lui Adam” care a fost creat din ,pământ feciorelnic", după cum arată Sfântul Irineu ${ }^{19}$.

Așadar, pentru ca asemănarea să fie și mai izbitoare și la Întrupare participă întreaga Treime după cum mărturisește arhanghelul Gavriil Fecioarei Maria (Luca 1,35), după cum mărturisim și în Crez „S-a întrupat de la Duhul Sfânt și din Fecioara Maria”, drept pentru care Sfântul Ioan Damaschin spune „de la Duhul Sfânt și în chipul celei dintâi faceri a lui Adam"20.

Sfântul Vasile cel Mare identifică în insuflarea dumnezeiască din Facere 2, 7, lucrarea Sfântului Duh, crearea sufletului după chipul Creatorului dar și harul Duhului, har primit la creație odată cu sufletul și pierdut prin păcat, dar, redat de Hristos după Înviere: „Căci Duhul este rânduit să creeze împreună cu Cuvântul cel viu, este putere vie și fire dumnezeiască, creștere negrăită din gură negrăită, în chip de negrăit și ca suflarea trimisă în om și după chipul trupesc arătat de Domnul, restabilit din nou de El prin suflare, căci trebuia să aducă prin înnoirea de la început

${ }^{17}$ Sfântul VASILE CEL MARE, „Omilie la psalmul XLVIII, 8”, în Tâlcuire duhovnicească la Psalmi, trad. Dumitru Fecioru, Bucureşti, Edit. Institutului Biblic și de Misiune al Bisericii Ortodoxe Române, 2000, p. 213.

${ }^{18}$ Matei 8, 29; 14, 33; 16, 16; 27, 54; Marcu 1, 1; 1, 11; 3, 11; 15, 39; Luca 1, 35; 3, 22; 3,$38 ; 4,41 ; 8,28 ; 22,70 ;$ Ioan 1,$34 ; 1,49 ; 6,69 ; 9,35 ; 11,4 ; 20,31$; Faptele Sfinților Apostoli 9, 20; Efeseni 4, 13; Evrei 4, 14; 10, 29; I Ioan 3, 8; 5, 10; 5, 13; 5, 20; II Ioan 1,3 ; Apocalipsă 2, 18 .

${ }^{19}$ Sfântul IrINEU De Lugdunum, Demonstrația propovăduirii apostolice, 32, trad. Remus

Rus, București, Edit. Meteor Publishing, 2016, p. 125.

${ }^{20}$ Sfântul IoAn Damaschin, Dogmatica, III,..., p. 115. 
înnoirea și reunirea de acum. Deci, L-a întipărit prin suflare (Duhul), nefiind altul decât cel ce a fost insuflat dintru-început, ci Acelaşi prin Care a dat Dumnezeu insuflarea, atunci cu sufletul, iar acum în suflet. Așa lucrează Dumnezeu, nu prin mișcarea unor mâini trupești, ci prin lucrarea Cuvântului celui viu și prin dăruirea Duhului Care face viu"21.

Prin Întruparea și Învierea Sa din morți Hristos restaurează firea umană și-i redă harul dumnezeiesc actualizând crearea omului, drept pentru care Sfântul Vasile cel Mare vede o similitudine între suflarea lui Dumnezeu în fața lui Adam și suflarea lui Hristos în fețele Sfinților Apostoli, în prima zi a învierii, zicând: ,în lucrarea de reînnoire a omului, de a-i reda harul-pe care îl primise din suflarea lui Dumnezeu, dar îl pierduse-Domnul, suflând peste ucenici a zis : «Luaţi Duh Sfânt. Cărora veţi ierta păcatele, vor fi iertate şi cărora le veţi ţine, vor fi ţinute» (Ioan 20, 22- 23)"22. Această redare a harului o primește omul în Taina Sfântului Botez când în chip simbolic preotul suflă de trei ori peste faţa catehumenului $^{23}$.

Dacă prin alcătuirea sa dublă: trup și suflet, Adam este un microcosmos, un mijlocitor între lumea materială și lumea spirituală, Noul Adam, Hristos, prin Întrupare, devine „Mijlocitorul între Dumnezeu şi oameni” (I Timotei 2, 5), căci „El 1-a unit pe om cu Dumnezeu și a săvârșit împăcarea și comuniunea dintre Dumnezeu și om, pentru că nu am fi putut dobândi în niciun alt mod participarea la nestricăciune dacă nu ar fi venit El la noi"24. La facerea primului Adam îngerii cântau (cf. Iov 38, 7), lucru care s-a petrecut și la nașterea lui Hristos, al doilea Adam (Luca 2, 13-14). Primul Adam a fost pus stăpân al pământului (Facere 1, 28) și animalele îl ascultau (Facere 2, 19-20), autoritate pierdută odată cu intrarea păcatului în lume (Facere 3, 17), Noul Adam S-a născut într-o

${ }^{21}$ Sfântul VASILE CEL MARE, Impotriva lui Eunomie. Expunere a credinței niceene, trad. Lavrentie Carp, Piatra Neamț, Edit. Crigarux, 2007, p. 179.

22 „Despre Duhul Sfânt, 16,” în PSB, 12, Sfântul VASILE CEL MARE, Scrieri partea a treia, Despre Sfântul Duh. Corespondență (Epistole), trad. Constantin Cornițescu și Teodor Bodogae, București, Edit. Institutului Biblic și de Misiune al Bisericii Ortodoxe Române, 1988, p. 55.

23 „Rânduiala dinaintea Sfântului Botez”, în AGHIASMATAR, București, Edit. Institutului Biblic şi de Misiune Ortodoxă, 2016, p. 25. Suflarea ca act liturgic din timpul Botezului o găsim și la sfințirea apei și la sfințirea untdelemnului (vezi p. 41-42)

24 Sfântul IRINEU DE Lugdunum, Demonstrația propovăduirii apostolice, 31, p. 124. 
iesle printre animale pentru a restaura împăcarea dintre om și animale ${ }^{25}$, după cum spune profetul Isaia: „Boul îşi cunoaşte stăpânul şi asinul ieslea domnului său" $(1,3)$, autoritate pe care o vor dobândi și sfințiii' ${ }^{26}$.

\section{Crearea femeii versus crearea Bisericii}

Dacă mai sus am prezentat moartea ca predarea a omului lui Dumnezeu, prin izbăvirea din robia patimilor, la polul opus, se întâlnește la părintele Stăniloae ideea că moartea este slăbirea sufletului în trup, slăbire cauzată de ruperea comuniunii cu Dumnezeu, prin păcate.

Referitor la crearea femeii găsim informații în cartea Genezei unde se spune: „Atunci a adus Domnul Dumnezeu asupra lui Adam somn greu; şi, dacă a adormit, a luat una din coastele lui şi a plinit locul ei cu carne. Iar coasta luată din Adam a făcut-o Domnul Dumnezeu femeie şi a aduso la Adam. Şi a zis Adam: „Iată aceasta-i os din oasele mele şi carne din carnea mea; ea se va numi femeie, pentru că este luată din bărbatul său" (Facere 2, 21-23). Tâlcuind acest episod scripturistic, Sfântul Simeon Noul Teolog vede în crearea Evei din Adam întruparea Logosului din Fecioara Maria, ,căci așa cum pe femeie a făcut-o din coasta aceluia, tot așa, împrumutând și luând făă sămânță trup din fiica lui Adam din Maria, Pururea-fecioară și Născătoare de Dumnezeu, S-a născut în chip asemănător întâiului plăsmuit ca, precum acela s-a făcut prin călcarea poruncii început al nașterii noastre întru stricăciune și moarte, așa și Hristos Dumnezeu, prin împlinirea întregii dreptăți (Matei 3, 15), S-a făcut pârgă a replăsmuirii și nemuririi noastre întru nestricăciune"27.

Restaurarea lui Adam în Hristos este oglindită în relația dintre crearea Evei din Adam și nașterea lui Hristos, al doilea Adam, din Fecioara Maria, Noua Evă, având următorul raport Adam-Eva-Noua EvăNoul Adam, după cum arată Sfântul Simeon Noul Teolog ,că așa cum părticica luată din întreg trupul lui Adam a fost zidită ca femeie, așa iarăși

${ }^{25}$ Calinic Berger, Provocări ale gândirii și vieții ortodoxe astăzi - reflecții despre temeiurile creștine, p. 10.

${ }^{26}$ A se vedea volumul Când animalele vorbesc cu sfinții: sinaxar al sfintilor care au iubit animalele şi care au fost iubiți de acestea, trad. Florin Toader Tomoioagă, ClujNapoca, Edit. Renașterea, 2014.

27 Sfântul Simeon Noul Teolog, Discursuri teologice și etice, Scrieri I, ediția a II-a revăzută, trad. Ioan I. Ică jr, Sibiu, Edit. Deisis, 2001, p. 113. 
aceeași părticică luată fiind iarăşi din femeie să fie rezidită ca bărbat și să se facă un nou Adam (I Corinteni 15, 45), Domnul nostru Iisus Hristos"28.

De asemenea, Sfântul Simeon consideră coasta lui Adam o prefigurare a Bisericii și a Euharistiei „fiiindcă luând din Fecioară carnea, Hristos trebuia să umple din nou locul ei, așa cum a umplut odinioară și coasta lui Adam. Dar, fiindcă, acest lucru trebuia să se facă nu spre stricăciune, ci spre nestricăciune, umplerea s-a făcut cu Duhul, iar nu cu carne, ca firea lui Adam să se plăsmuiască din nou și cei ce aveau să se facă prunci ai lui Dumnezeu prin Duhul Sfânt, să ia nașterea din nou, și așa toți cei ce cred în El să se facă rude ale Lui și un singur trup"29.

Sfinții Părinți văd o paralelă între crearea Evei din coasta lui Adam şi nașterea Bisericii din coasta lui $\operatorname{Hristos}^{30}$, căci după mărturisirea Sfântului Ioan Teologul ,unul din ostaşi cu suliţa a împuns coasta Lui şi, îndată, a ieşit sânge şi apă" (Ioan 19,34), sângele și apa reprezentând cele două taine fundamentale ale Bisericii: Botezul și Euharistia ${ }^{31}$, după cum afirmă și Sfântul Ioan Gură de Aur: „A ieșit sânge și apă. Nu fără motiv şi la întâmplare au curs aceste două izvoare din coasta Mântuitorului; din ele s-a format Biserica. Cei ce sunt inițiați, cei ce au primit Botezul, înțeleg bine: ei care au fost renăscuți prin apă, și care sunt hrăniți cu acest sânge și din această carne. Din acest fericit izvor curg misterele și tainele noastre, ca, atunci când vă apropiați de paharul nostru cel minunat (Potirul) să veniți la el ca să beți ca și cum ați veni să puneți buzele la această coastă sfântă" ${ }^{\prime 2}$. Coastă care se dovedește a fi adevărata ușă care duce la Tatăl ${ }^{33}$ și care ne face ,părtaşi dumnezeieștii firi”” (II Petru 1,4).

Asemănările dintre cele două evenimente sunt izbitoare: Eva este creată din coasta lui Adam pe când acesta dormea, Biserica este creată din coasta lui Hristos când era mort pe Cruce, când dormea cu trupul ca un muritor; din coasta lui Adam a izvorât stricăciunea și moartea, iar din

${ }^{28}$ Ibidem, p. 164.

${ }^{29}$ Ibidem, p. 182.

${ }^{30}$ Brant Pitre, Isus Mirele: cea mai frumoasă poveste de dragoste a tuturor timpurilor, trad. Tatiana Niculescu, București, Edit. Humanitas, 2018, p. 151.

31 Joseph RAtZInger, papa Benedict al XVI-lea, Isus din Nazaret, trad. Alexandru Mihăilescu, București, Edit. RAO, 2010, p. 214.

32 Sfântul IOAN GURĂ DE AUR, ,Omilia 85, 3”, în Comentariu la Evanghelia de la Ioan, Oradea, Edit. Pelerinul Român, 2005, p. 477.

${ }^{33}$ Ion BuGA, Carantania şi Ghetsimani: cele patru ispitiri ale Mântuitorului și umanității, p. 169. 
coasta lui Hristos a izvorât vindecarea și viaţa ${ }^{34}$; Adam a recunoscut pe Eva a fi os din oasele sale și carne din carnea sa, Biserica este Trupul lui Hristos (Efeseni 1, 22-23; 5, 23).

Sângele și apa izvorâte din coasta lui Hristos îl arată „Mijlocitorul unui nou testament" (Evrei 9, 15), căci și Moise a stropit cu apă și cu sânge poporul spre a-1 sfinți și curăți și pentru a întări Legământul (Evrei 9, 18-22), la fel și Hristos ${ }^{35}$ spală păcatele poporului cu apa izvorâtă din coasta Sa care se dovedește a fi izvorul apei celei vii (cf. Ioan 4, 10-14; 7, 38; I Corinteni 10, 3-4), iar sângele Său vărsat în timpul Pătimirilor este prețul de răscumpărare (Efeseni 1, 7; I Petru 1, 18-19) pentru toți (I Timotei 2, 6). Astfel, toți oamenii sunt răscumpărați și împăcați cu Tatăl prin sângele Fiului curs pe Cruce din cauza bătăilor, spinilor și piroanelor, dar nu toți se împărtășesc de sângele sacramental izvorât din coasta Sa care, nu se dă decât împreună cu apa, adică celor Botezați, creștinilor „altoiți pe El” (Romani 6, 5).

Prin Întrupare, Hristos recapitulează pe Adam și restaurează chipul divin din om redându-i harul pierdut prin păcat, împăcând neamul omenesc cu Dumnezeu ca unul ce este singurul mijlocitor între Dumnezeu și om (I Timotei 2, 5). Astfel, din coasta Noului Adam se naște Biserica, Trupul lui Hristos, care prin Sfintele sale Taine îl face pe creștin părtaș dumnezeirii (cf. II Petru 1, 4), fiu și moștenitor al Împărăţiei.

\section{Referinţe bibliografice:}

1. BARClay, William, Analiză semantică a unor termeni din Noul Testament, trad. Doris Laurențiu, editor John F. Tipei, USA, Illinois, Wheaton, Edit. Societatea Misionară Română, 1992.

${ }^{34}$ Hierotheos Vlachos, Predici la marile sărbători, trad. Daniela Filioreanu, Galați, Edit. Egumenița, 2004, p.210.

35 Sfântul Ioan Damaschin spune în acest sens că Dumnezeu „S-a pogorât, în virtutea milostivirii Sale, spre robi și, făcându-se asemenea nouă, ne-a răscumpărat prin patima Sa din stricăciune. Ne-a izvorât nouă, din sfânta și preacurata Lui coastă, izvorul iertării. Apa izvorâtă din coasta Sa este spre renaştere și inundarea păcatului şi a stricăciunii, iar sângele este băutură pricinuitoare a vieții veșnice...Duhul reînoiește în noi starea după chipul și asemănarea lui Dumnezeu" - Sfântul IoAN Damaschin, Dogmatica, (IV,9), p. 188. 
2. BERGER, Calinic, Provocări ale gândirii și vieții ortodoxe astăzi reflecții despre temeiurile creștine, trad. Maria-Cornelia și Ioan I. Ică jr, Sibiu, Edit. Deisis, 2012.

3. GoJE, Ioan, Sfântul Irineu: apărător al învățăturii creștine, ClujNapoca, Edit. Renașterea, 2002.

4. Sfântul IOAN DAMASCHIN, Dogmatica, trad. Dumitru Fecioru, București, Edit. Institutului Biblic și de Misiune al Bisericii Ortodoxe Române, 2005.

5. Sfântul IOAN GURĂ DE AUR, Comentariu la Evanghelia de la Ioan, Oradea, Edit. Pelerinul Român, 2005.

6. Sfântul IRINEU DE Lugdunum, Demonstrația propovăduirii apostolice, 32, ediția a doua revizuită, traducere de Remus Rus, București, Edit. Meteor Publishing, 2016.

7. Lossky, Vladimir, După chipul şi asemănarea lui Dumnezeu, trad. Anca Manolache, Bucureşti, Edit. Humanitas, 2006.

8. PITRE, Brant, Isus Mirele: cea mai frumoasă poveste de dragoste a tuturor timpurilor, trad. Tatiana Niculescu, București, Edit. Humanitas, 2018.

9. RATZINGER, Joseph, papa Benedict al XVI-lea, Isus din Nazaret, trad. Alexandru Mihăilescu, București, Edit. RAO, 2010.

10. RăDUleanu, Boris, Innoirea lumii în Iisus Hristos, București, Edit. Bonifaciu, 1997.

11. Sfântul Simeon Noul Teolog, Discursuri teologice și etice, Scrieri I, trad. Ioan I. Ică jr, Sibiu, Edit. Deisis, 2001.

12. Sfântul VASILE CEL MARE, Impotriva lui Eunomie. Expunere a credinței niceene, traducere și note de Ieromonah Lavrentie Carp, Piatra Neamt, Edit. Crigarux, 2007.

13. Vlachos, Hierotheos, Predici la marile sărbători, trad. Daniela Filioreanu, Galați, Edit. Egumenița, 2004. 